\title{
China's Low Carbon Energy Policy: National Dilemmas and Global Perspectives
}

\author{
OLE ODGAARD
}

\begin{abstract}
China has embarked on a more sustainable path to becoming an industrialized and developed nation. The main drivers are the insecurity of fossil energy supply, widespread pollution, and acute water shortage caused by exploitation of coal in northern China. China is now a leading nation regarding deployment of green energy technologies. But at the same time coal-based power plants seem to be commissioned more extensively than prescribed in the Five-Year Plans. Many local governments favour short term economic growth and employment creation and resent more costly green policies, despite pressure from the central government. In the coming decades, China will be the main contributor to the growing global energy consumption of especially oil, coal and nuclear power; it will also be the main contributor to global growth in $\mathrm{CO}_{2}$ emissions. However, recent policy initiatives launched by the central government aim to bypass the local opposition to greener development by introducing more economic incentives to reduce fossil fuel demand. The outcome of these attempts to weaken federalist governance will be imperative for a more sustainable development of China's energy sector.
\end{abstract}

Keywords: China; Coal; Renewable energy; Energy governance

\section{Introduction}

China's energy consumption has multiplied in a few decades due to high economic growth rates. The energy sector relies heavily on coal, far more than most other countries. China's coal reserves are abundant and many local governments and industries prefer and protect this relatively cheap energy source in order to reap the short term benefits in terms of economic growth and employment creation. However, the flip-side of the coin is a seriously unsustainable form of growth, which may impede long term economic growth, unless the central government succeeds in its recent attempts to devise new incentives to reduce the demand for fossil fuels and embark on a more low carbon energy policy. 


\section{Materials and Method}

This article aims to provide a thorough overview of China's energy policy, its challenges and future national and global impact. Particular attention will be given to the energy production and supply policies. A macro perspective will be applied, focusing on availability of energy resources and the policies employed to develop the energy supply sector in a sustainable way. The policies regarding final energy consumption and energy efficiency will receive little attention in this analysis.

An important part of the analysis consists of quantitative assessments of China's energy policy and development. Data from the autonomous and internationally recognized International Energy Agency (IEA) will be used, as they are generated according to international standards and provide coherent and comparable information. China's National Statistical Bureau will also be a major data source. It is acknowledged that Chinese statistics are not without lacunae, and the data will be interpreted as trends rather than details.

The quantitative trends will be qualified in relation to policy dilemmas, national interest groups, resource constraints and other factors of importance for the development of China's future energy policies. Finally, some important key challenges are identified, which may be crucial indicators for the achievement of China's ambitious future green targets.

The analytical method applied relies on the perception of China's political system as a 'fragmented authoritarian' mode of government. The energy policy-making process is thus conceived as protracted and shaped over a long period of time, and at the same time disjointed and influenced by different and loosely coordinated actors (Lieberthal and Oksenberg 1988). The quasi-federal role of local governments is also found to be of major importance in the implementation of energy policies. The local energy or environmental protection bureau may have reporting responsibilities to both the central government's resort ministry (e.g. Ministry of Environment) and to the local city mayor or provincial governor (Sinkule and Ortolano 1995: 10-21). This has significantly strengthened local government bodies in the reform era since 1978.

\section{China's Growing Energy Consumption}

China has since the late 1970s had economic growth rates of almost 10 percent annually. This has had a significant impact on energy consumption, which has increased more than fivefold from 1980 to 2010. The 
energy consumption is mainly based on coal. As shown in Table 1, coal has contributed with about 70 percent of China's energy consumption. The share has declined only marginally during the last decades, i.e. by about 8 percentage points in 30 years.

TABLE 1. China's Energy Consumption and Energy Types, 1980-2012

\begin{tabular}{|c|c|c|c|c|c|}
\hline Years & $\begin{array}{c}\text { Energy } \\
\text { Consumption } \\
\text { (million ton coal } \\
\text { equivalents) }\end{array}$ & \multicolumn{5}{|c|}{ Energy Consumption (\%) } \\
\hline & & Coal & Oil & $\begin{array}{c}\text { Natural } \\
\text { Gas }\end{array}$ & $\begin{array}{c}\text { Non-fossil energy: } \\
\text { renewable energy and } \\
\text { nuclear power }\end{array}$ \\
\hline 1980 & 603 & 72.2 & 20.7 & 3.1 & 4.0 \\
\hline 1990 & 987 & 76.2 & 16.6 & 2.1 & 5.1 \\
\hline 2000 & 1,455 & 69.2 & 22.2 & 2.2 & 6.4 \\
\hline 2005 & 2,360 & 70.8 & 19.8 & 2.6 & 6.8 \\
\hline 2010 & 3,249 & 68.0 & 19.0 & 4.4 & 8.6 \\
\hline 2011 & 3,480 & 68.4 & 18.6 & 5.0 & 8.0 \\
\hline 2012 & 3,617 & 66.6 & 18.8 & 5.2 & 9.4 \\
\hline 2013 & 3,750 & 66.0 & 18.4 & 5.8 & 9.8 \\
\hline
\end{tabular}

Source: China Statistical Yearbook 2014.

Note: The share of non-fossil energy fluctuates naturally, as hydropower varies according to the annual depreciation. Non-commercial biomass used for heating and cooking in rural areas is excluded from the statistics.

Energy consumption has grown significantly faster than expected. The Chinese government's long-term goal for energy consumption was that gross domestic product (GDP) should quadruple from 2000 to 2020, while energy consumption must only be doubled. However, energy consumption doubled by 2008, almost three times faster than expected.

This is due to high economic growth. The growth rates in previous Five-Year Plans seem to be continuously overtaken: the annual GDP growth rate was planned at 7.5 percent in the 11th Five-Year Plan (20062010), but the actual growth rate was 11.2 percent (World Bank 2013).

This sharp increase in energy consumption is clearly visible in the commissioned capacity of power plants. From 2005 to 2010, China installed an average of $1,800 \mathrm{MW}_{\text {el }}$ per week, mainly coal-based. China now uses twice as much coal as all OECD countries combined. In 2009 and 2010, China's incremental demand equalled the EU's total coal consumption in 2010 (IEA 2012). While China in 1990 accounted for only a quarter of the world's coal consumption, in 2011 the proportion 
increased to as much as 49 percent. By 2010, China overtook the USA to become the world's largest energy consumer (IEA 2012), and in 2011 China accounted for 21 percent of global energy demand (IEA 2013b: $572 ; 620)$. China doubled its share of the global energy demand in the course of just 20 years.

However, the share of non-fossil energy has been on the increase especially since 2007, which may signal a new trend. Hydropower is and is likely to remain the dominant source of renewable energy, but nuclear power and wind power are expected to gain market shares in the coming years. It is noteworthy that in periods with high economic growth in China, the share of coal consumption increases, while a relatively low economic growth is often accompanied by a relative decline in the coal supply. Thus the share of non-fossil energy has increased from 8.0 percent in 2011 to 9.8 percent in 2013. ${ }^{1}$ The question of whether this is a temporary phenomenon or a new trend warrants attention and will be discussed later in this article.

\section{Urgent Need for a Reduction in Fossil Fuels}

China's steady energy growth has relied on fossil fuels, despite an urgent need to embark on a more sustainable path. China has for several years been trying to reduce the use of fossil fuels, for at least four compelling reasons:

First, China's government is increasingly aware that China cannot copy the Western development model and that it has to embark on a more sustainable development path at an earlier stage. There are simply not enough natural resources available. This scarcity applies not only to energy, but also water and other resources related to exploitation of energy (ADB 2012). China's water resources per person are only one third of the global average (World Bank2013a, Table 3.5). To make things worse, China's scarce water resources are very unevenly distributed, leaving 46 percent of China's population residing in northern China with only about 20 percent of the water resources to cater 65 percent of China's cultivated land (FAO 2011: 227). Most of China's exploitation of coal is located there, as are the majority of coal-fired power plants.

China's energy sector embodies this dilemma. Coal-related industries such as mining production and power generation are extremely water-intensive. Coal mines depend on water to extract, wash and process the coal, while coal-burning power plants need water to 
create steam and cool generating systems (Chan 2013). ${ }^{2}$ China's coal mining, processing and thermal power plants alone accounted for 15-20 percent of all water consumed nationally in $2010 .{ }^{3}$ With the present policies, the coal sector will increase its share of the total water demand to 27 percent in 2020 (IRENA 2014: 35). The tangible dilemma is that there are seemingly limited alternatives to the expansion of coal-based industries in the already water-stressed areas in north and northwest China. More than 80 percent of China's coal reserves and 85 percent of the total power generation capacity lie in water-stressed or water-scarce regions (IEA 2013f; IRENA 2014).

As of July 2012, China planned to construct 363 coal-fired power plants, with a combined generating capacity exceeding 558 Giga Watt (GW) (WRI 2012). This amounts to an almost 75 percent increase in coal-fired generating capacity. Fifty-one percent of these new coal-fired power plants would be built in areas of high or extremely high water stress.

If all of the proposed plants are built, the coal industry is expected to withdraw as much as 10 billion $\mathrm{m}^{3}$ of water annually by 2015 . That is more than a quarter of the water available for withdrawal every year from the Yellow River, which is already becoming depleted. Other major takeaways are limited, as 60 percent of the total proposed generating capacity is concentrated in six provinces, which only account for 5 percent of China's total water resources (WRI 2013). The total volume of water withdrawn by the Chinese power sector will grow from 102 billion $\mathrm{m} 3$ in 2010 to 124 billion $\mathrm{m} 3$ in 2030 in a business-as-usual scenario. ${ }^{4} \mathrm{~A}$ decreasing reliance on coal is now a necessity, especially in the power sector. In the words of the IEA, 'Water constraints could make the expected increase in thermal power output unachievable' (2013: 95).

Secondly, China's supply of coal is also increasingly unstable due to logistical problems. The coal mines are located in northern and northwestern China, relatively far away from industrial centres in eastern and southern China. Transport constitutes a real bottleneck for coal, which already makes up as much as almost 50 percent of the total rail transport in China (Jianjun Tu and Johnson-Reiser 2012: 4-6). In addition, coal is retrieved from ever deeper layers, and the new coal resources are located even further to the west. Since these factors increase costs, coal is imported from the world market.

China's domestic railway bottleneck could to some extent be solved by locating all new coal-fired power plants near the coal mines in 
northern and northwestern China. The electricity may then be transmitted to the consumption centres in eastern China by ultra-high voltage lines. At the time of writing, this option is being considered, though it may prove unrealistic due to the acute water shortage in the coal-endowed areas.

Another option is to import the coal. China became a net importer of coal in 2009 and replaced Japan as the world's largest coal importer in 2011 (IEA 2013a). Net import of coal is expected to range at 7-8 percent of the country's coal consumption until 2035. This net-import will average about 15 percent of the total trade of coal on the world market in this period. This is unlikely to be a problem, as many stable and politically friendly countries can cover this demand. However, the domestic supply situation is becoming increasingly complex.

Thirdly, China became a net importer of oil in 1993 and of natural gas in 2007; it aims to reduce its increasing dependence on imports of natural gas and oil. China's fossil fuels reserves are low, and the security of supply is threatened by large future imports (see Figure 1).

FIGURE 1. China's Net Imports of Energy Compared to the Total Energy Consumption: 1990-2035

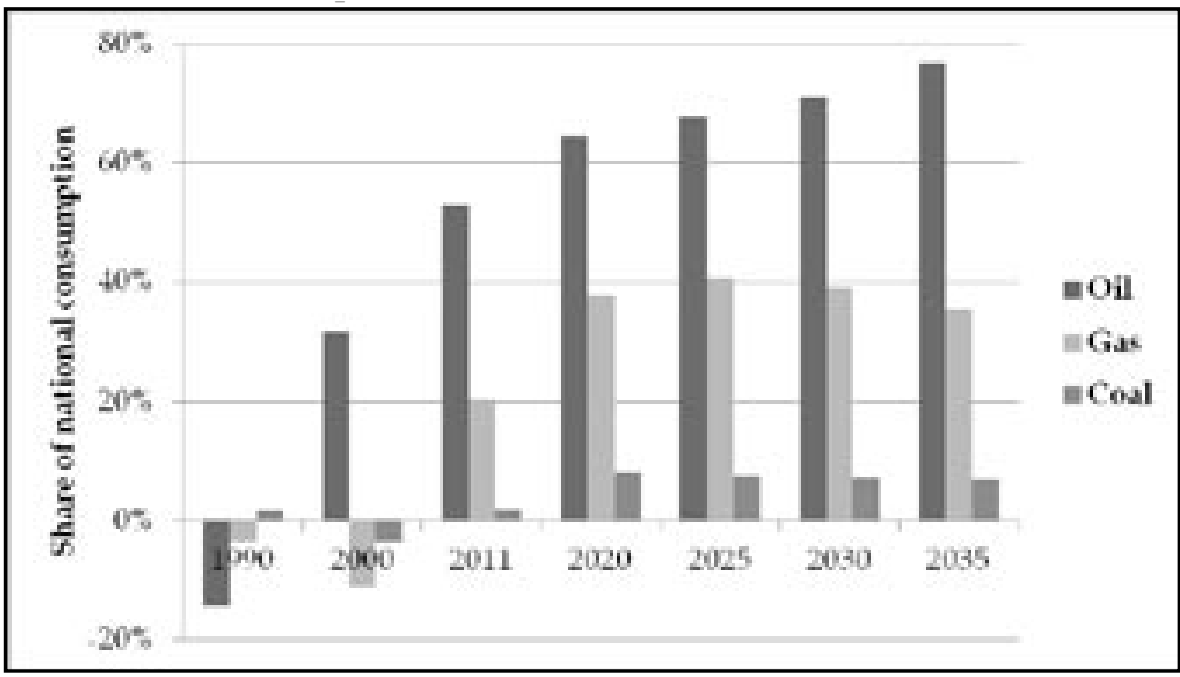

Sources: Author's calculations based on data from the IEA, World Energy Outlook 2013, World Energy Outlook 2011, Gas Information 2013, Coal Information 2013, and BP Statistical Review of World Energy-June 2011. ${ }^{5}$

The future demand for gas will rise sharply and precipitate a large import. From 2020 China would have to import almost 40 percent of its entire consumption of gas. China aims to ensure a stable and reliable import of natural gas, which appears to be a realistic 
scenario, if handled properly. Major pipelines from neighbouring countries could cover more than half of the import requirements in 2035. In addition, there are excellent opportunities for imports of liquefied natural gas from countries and regions, such as Australia, Malaysia and Indonesia, which are generally politically stable or at least not likely to be a supply threat for China. Furthermore, China has potential for its own production of non-conventional gas in the form of shale-gas and coal bed methane, etc.

However, security of supply of oil is a serious concern. China now imports more than half of its oil, and the import dependence is projected to reach an alarming 77 percent in 2035. By 2013 China had overtaken the USA as the world's largest oil importer, and China will remain the global top importer for the foreseeable future (see Figure 1). China's two pipelines and the third presently under construction will cover barely 10 percent of the oil import demand in 2030. The vast majority must be imported from overseas, and almost half of China's oil imports come from unstable countries in the Middle East. This proportion has not declined in recent years despite imports from new supply countries. The oil import is China's Achilles Heel (Odgaard and Delman 2014).

Fourthly, China is today one of the world's most polluted countries. The main cause of this is use of coal; coal accounts for 90 percent of the sulphur dioxide pollution and half of the particulate pollution (WRI 2012A). ${ }^{6}$ Twenty of the world's 30 most polluted cities are located in China (World Bank \& Development Research Center of the State Council 2012: 70). Less than 1 percent of the 500 largest cities meet the air quality standards recommended by the WHO (ADB 2012: 55). China has the highest exposure to air particle pollution $\left(\mathrm{PM}_{2.5}\right)$ in the world. ${ }^{7}$ More than 110 million people live in cities, which are characterized as 'very harmful' by the Ministry of Environment. Outdoor air pollution contributed to about 1.2 million premature deaths in 2010 in China alone, and it currently ranks at number four among all risk factors contributing to the health burden in China (Health Effect Institute 2013). Air pollution has decreased life expectancy by 5.5 years among Northern China's 500 million inhabitants (Chen et al. 2013). Almost half of China's cities were exposed to acid rain in 2011 (Ministry of Environmental Protection 2012: 30). At least 10 percent of the agricultural land is contaminated with heavy metals (Holdaway 2013: 275). 
The costs of environmental degradation and resource depletion in China approached 10 percent of GDP in the past decade. If the external costs of pollution - in the form of increased medication expenses, fewer food crops and environmental degradation etc. - were subtracted from GDP, more provinces today would have a negative economic growth rate instead of the published positive annual growth rates (World Bank \& Development Research Center of the State Council 2012: 39). Pollution control costs will increase dramatically in the coming decades. In 2020 the costs of local pollution control for $\mathrm{SO}_{2}, \mathrm{NO}_{\mathrm{x}}$ and $\mathrm{PM}_{2,5}$ is expected to be twice as high as in 2011, and in 2035 the costs will have at least tripled (IEA 2013: 41). Thus, the replacement of coal and oil by more sustainable energy sources is a key priority for China's overall development. This need has been acknowledged and addressed by the Chinese leadership in its new policies.

\section{Challenges for Green Policy Initiatives}

China has launched several, concerted attempts to develop more renewable energy and a domestic market for green energy technology. This development has been facilitated by new support mechanisms, administrative set-ups and progressive Five-Year Plans. The local governments and the largest energy companies are requested to establish additional wind turbines, hydroelectric plants and biomass-based power stations, and to improve the local environment and so forth.

In order to strengthen the phasing in of renewable energy, the 11th Five Year Plan (2006-10) endorsed the target of 10 percent renewable energy of the total energy consumption in 2010. However, this target was not achieved. The first indication of this was, when the Chinese leadership in September 2009 introduced a target for non-fossil energy rather than renewable energy, i.e. nuclear power should be included in the target (Wang et al. 2011). Nevertheless, China achieved only 8.6 percent non-fossil energy in 2010 instead of 10 percent renewable energy. Since China has established a large capacity of nuclear power plants in recent years, there has been only a modest increase in the share of renewable energy, which is far below the planned outcome (see Table 2, below).

China's official target of 15 percent renewables in 2020, according to the 'Medium and Long Term Development Plan for Renewable Energy in China', was also changed to 15 percent non-fossil sources (Run et al. 2011: 2746). Similarly, the renewable electricity targets for the 14 
TABLE 2. Selected Targets for Energy in 5-Year Plans and Other Medium and Long-Term Plans

\begin{tabular}{|c|c|c|c|c|c|c|}
\hline & & $\begin{array}{l}\text { 11th FYP } \\
\text { Target } \\
(2010)\end{array}$ & $\begin{array}{l}\text { 11th FYP } \\
\text { Actual } \\
\text { result } \\
(2010)\end{array}$ & $\begin{array}{l}\text { 12th FYP } \\
\text { Target } \\
(2015)\end{array}$ & $\begin{array}{l}2017 \\
\text { Target }\end{array}$ & $\begin{array}{l}2020 \\
\text { Target }\end{array}$ \\
\hline 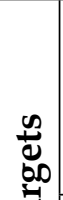 & $\begin{array}{l}\text { Share of non- } \\
\text { fossil energy in } \\
\text { primary energy } \\
\text { (renewables and } \\
\text { nuclear energy) }\end{array}$ & $\begin{array}{l}10 \% \\
\text { (RE only) }\end{array}$ & $8.6 \%$ & $11.4 \%$ & $13 \%$ & $15 \%$ \\
\hline 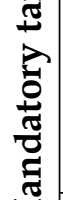 & $\begin{array}{l}\text { Energy } \\
\text { consumption per } \\
\text { GDP unit } \\
\text { (= energy } \\
\text { intensity) } \\
\end{array}$ & $-20 \%$ & $-19.1 \%$ & $-16 \%$ & - & - \\
\hline$\Sigma$ & \begin{tabular}{|l|}
$\mathrm{CO}_{2}$ emissions \\
per GDP unit \\
(= carbon \\
intensity) \\
\end{tabular} & - & $-20.5 \%$ & $-17 \%$ & - & \begin{tabular}{|l|}
$-40 \%$ to \\
$-45 \%$ \\
compared \\
to 2005 \\
\end{tabular} \\
\hline & $\begin{array}{l}\text { Share of coal in } \\
\text { primary energy } \\
\text { consumption }\end{array}$ & - & $68 \%$ & $65 \%$ & $65 \%$ & $62 \%$ \\
\hline 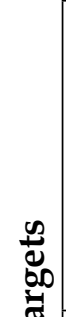 & $\begin{array}{l}\text { Target for } \\
\text { all } 4 \text { grid } \\
\text { corporations: } \\
\text { Share of } \\
\text { non-hydro } \\
\text { renewables in } \\
\text { total electricity } \\
\text { consumption } \\
\end{array}$ & $1 \%$ & $\begin{array}{l}2 \text { out of } 4 \\
\text { fulfilled } \\
\text { target }\end{array}$ & - & - & $3 \%$ \\
\hline 茪 & $\begin{array}{l}\text { Target for } 14 \\
\text { largest power } \\
\text { companies: } \\
\text { Share of non- } \\
\text { hydro renewable } \\
\text { capacity }\end{array}$ & $3 \%$ & $\begin{array}{l}7 \text { out } \\
\text { of } 14 \\
\text { fulfilled } \\
\text { target }\end{array}$ & $6.5 \%$ & - & $10 \%$ \\
\hline & $\begin{array}{l}\text { Total primary } \\
\text { energy } \\
\text { consumption } \\
\text { (Million tons } \\
\text { coal equivalents) }\end{array}$ & - & 3,250 & 4,000 & - & - \\
\hline & $\begin{array}{l}\text { Electricity } \\
\text { consumption } \\
(\mathrm{TWh})\end{array}$ & - & 4,200 & 6,150 & - & - \\
\hline
\end{tabular}

Note: It is unclear whether the 2017 targets are mandatory or indicative.

Sources: Collated by author from data drawn from several sources. ${ }^{8}$ 
largest power companies and the 4 grid corporations stipulated in the 'Renewable Energy Law' of 2006 were not met. The targets for renewable electricity generation were intended to help the development of non-hydro power renewable energy and they were, in contrast to the other targets, indicative and not mandatory.

Therefore, the share of non-fossil power generation has only been raised from 17 percent in 2000 to 19 percent in 2011. However, the under-fulfilment of the renewable energy target does not imply that only a limited capacity of green energy technologies is being deployed. On the contrary, due to high economic growth, even a stagnant market share for renewables would actually represent a sharp increase in commissioned power generation equipment. But the flip-side of the coin is that the commissioned capacity of coal-fired power plants has increased even more.

Surprisingly, in the first years of the current Five-Year Plan (20102015), actual coal consumption continued to grow so extensively that the attainment of the official goal for restricted coal demand was set against reasonable odds. In September 2013, the State Council revised an important target: the achievement of 65 percent coal of the total energy demand should now be met in 2017 instead of 2015 (see Table 2). Although the so-called 'Air Pollution Prevention and Control Action Plan' (State Council 2013) was launched as an active response to the widespread pollution in Chinese cities, it actually introduced targets that were more conservative and obsolete than some of the existing ones.

A plausible explanation could be that the postponement of the target for coal took into account that the coal-fired power plant sector may expand more than planned. According to the Five-Year Plan of 2010-2015, a total of $300 \mathrm{GW}$ of coal-fired power capacity should be added from 2011 to 2015. But in a detailed study the World Resource Institute has revealed the planning of $557 \mathrm{GW}$ coal-fired power plants in July 2012. This amounts to an almost 75 percent increase in coal-fired generating capacity compared to the 45 percent increase detailed in the Five-Year Plan. However, not all of the approved coal power plants will be commissioned, as high market prices for coal and low, regulated prices for electricity often make it a loss-running business (Yang 2012). This factor has modified the expected boom in newly established coal power capacity, as supported by recent statistics. Sixty-six percent of China's total energy consumption was made up by coal in 2013 (see Table 1), thus the attainment of the targeted share of 65 percent in 2015 becomes feasible. One possible explanation for this adjustment is that the international economic crisis has slowed down China's growth and export of energy intensive industrial products more 
than expected, similarly to the situation at the end of the 1990s when the share of coal declined during the low growth years, but when the normal high growth reappeared in the 2000s, the accompanying demand for energy brought back higher coal shares.

A noteworthy new regulation is that coal-fired power plants will only be permitted if they cogenerate heat as combined heat and power plants. Nuclear power was supported by the target of 50 GW by 2017. Significant progress for some targets should be possible in the coming years, provided the targets are followed through in implementing the more detailed action, i.e. by government support schemes and strict supervision of the actual implementation.

Thus, some key energy targets in the past Five-Year Plan have not been fulfilled at the local level, despite ambitious efforts and centrally orchestrated initiatives. But new central policies and lower economic growth may signal a new trend, though these are as yet unclear. However, IEA explicitly states that China's diversification from coal all depends upon 'coal-to-gas and coal-to-liquid projects or projected coal bases linked through ultra-high voltage lines to areas of consumption' and 'a scenario of peak coal in China is only credible if economic growth in China is significantly lower than assumed' (IEA 2014: 4-8). The most credible forecasts of China's long-term development is offered by IEA in its annual World Energy Outlook, which also offers comparable perspectives via-a-via other countries and regions.

\section{China's Energy Sector in a Global Perspective}

The dramatic growth in China's total energy consumption has meant that China now contributes most to the incremental global demand for coal and oil and also therefore to $\mathrm{CO}_{2}$ emissions (see Figure 3). This will continue in the future despite the new Chinese goals for more non-fossil energy and $\mathrm{CO}_{2}$-intensity improvement.

If all China's green goals are fulfilled, China's use of coal in absolute terms will still increase significantly. The planned expansion of coalfired power plants in the 12th Five-Year Plan will increase its capacity of coal fired power plants by 45 percent, i.e. an additional capacity that is larger than the aggregate capacity of all coal fired power plants in the EU. Even if China employs the most energy efficient energy technologies, the use of coal will increase significantly. From 2015 onwards, the major increase in China's coal demand will take place in the energy intensive industries, not in the power sector. 
China's increased coal consumption will account for almost 60 percent of the global net growth from 2011 to 2020. Interestingly, China's

FIGURE 2. China's Share of Incremental Growth in Global Energy and CO2-emissions: 2011-2035

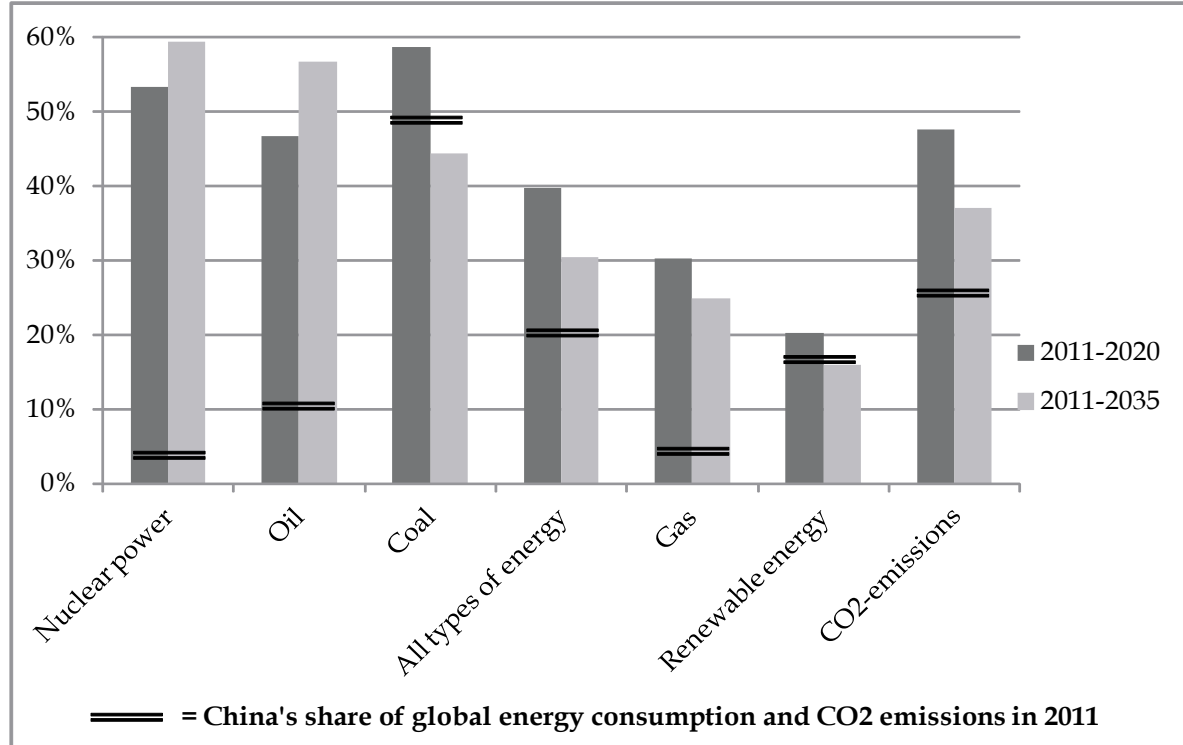

Note: The scenario is based on the assumption that all China's official goals for increased non-fossil energy are attained, i.e. IEA's New Policies Scenario.

Source: Author's calculations based on IEA (2013B).

incremental demand for oil and nuclear power will make up about half of the global net growth until 2020. In 2011 China accounted for 11 percent and 4 percent of the global demand for oil and nuclear power, respectively. China's contribution to the global net-growth in coal and gas consumption is set to decline after 2020. However, China's share of the global coal consumption changes only marginally from the high level of 50 percent to 49 percent in 2035.

China's impact on the global growth in oil consumption will further increase after 2020, so China's share of the global net growth will expand to 57 percent from 2011 to 2035 . China's oil consumption will grow significantly due to the sharp increases in transport vehicles and private cars. At the time of writing, there are 500 cars per 1,000 Europeans, while there are only 36 cars per 1,000 Chinese people (Birol 2013), thus the potential market is huge. The number of cars has already increased from 4 million light duty vehicles in 2000 to about 60 million in 2010; this number is expected to rise to 430 million in 2035 (IEA 2013B: 513). The consequence of this rise is that China will account for 16 percent of global oil consumption in 2035, an increase from 11 percent in 2010. 
Although China currently uses only 4 percent of the world's natural gas, by 2035 it will account for 11 percent of the global gas consumption. A notable development is that China will commission so many new nuclear plants that it will contribute with 59 percent of the global netgrowth towards 2035. By 2035 one in four of all nuclear power plants worldwide is expected to be located in China; in 2011 the figure was only 3 percent. This means that China until 2035 will account for onethird of the net growth in global energy consumption. While in 1990 China spent half as much energy as the US, by 2015 China is the world's largest energy consumer, a position which is projected to continue until 2035, when the country will use 81 percent more energy than the US (IEA 2013B: 584; 620).

China's share of global CO2-emissions was 26 percent in 2011. China's share of the global net growth will range at 37 percent in the period 2011 to 2035. Interestingly, the incremental share of renewable energy towards 2035 is lower in China compared to other countries and regions. China's share of net growth in renewable energy ranges at 16 percent, almost the same share as China's share of the global total is today.

\section{China's Global Impact on Non-fossil Energy Demand}

China's modest contribution to the current as well as incremental global growth of renewables until 2035 must be interpreted with caution, as traditional biomass for cooking and heating is included in the IEA's category of renewable energy. As this traditional use of biomass will be replaced by the use of biomass in modern power plants etc., the deployment of modern renewable technologies will reach a higher share than indicated by the global net-growth figure of 16 percent from 2011 to 2035. The required statistical method to make international comparisons is, however, available for power generation.

China's development of renewable energy has progressed substantially more in the power sector compared to the heat sector, transportation or other sectors. A large stock of new hydropower plants has been installed in recent years. By 2005 China had 117 GW of hydropower, which more than doubled to $249 \mathrm{GW}$ in 2012. In 2005 China had $1 \mathrm{GW}$ wind turbines on-grid, which rose sharply to $63 \mathrm{GW}$ in 2012. The capacity of biomass-based power plants expanded from $2 \mathrm{GW}$ to $8 \mathrm{GW}$ in the same period, while the capacity of solar PV increased from almost zero in 2008 to 4 GW in 2012 (CNREC 2013). Nuclear power has also increased significantly. 
Interestingly, in the Chinese power sector, renewables accounted for only slightly more than one-third of the capacity added in 2011, compared to almost half worldwide and 71 percent in the EU (REN21 2012: 13-14). Renewables are expected to comprise 40 percent of China's newly installed power capacity in the present Five-Year Plan (2010-15) compared to 87 percent worldwide in the same period (Author's calculations, IEA 2012A: 554; 574).

However, new figures on China's new power generation equipment in 2013 shed an interesting light on a possible new trend. China's new renewable power capacity surpassed new fossil fuel and nuclear capacity for the first time (REN21 2014: 14). This is backed up by other analyses, which suggest a breakthrough for wind power and to a lesser extent solar power, thereby supplementing hydropower as a main future power source.

Thus, China has commissioned a large stock of all types of power generating technologies, both renewables and fossil-based. Measured in GW, a large growth in the incremental renewable power plants takes place after 2008. However, their relative importance is less impressive, as more fossil-based power plants are commissioned, although the most recent figures from 2014 may suggest a new trend with a significant increase in commissioned renewable power capacity (National Statistical Bureau 2014). It is too early to pass any judgements on a possible new green power policy. The most credible scenario, as noted, is developed by IEA, which will be elaborated upon below.

China's global share of the incremental power generation towards 2035 is shown in Figure 4. China's increased demand for renewablebased power until 2035 will make up almost 30 percent of the global incremental demand for renewable electricity. This is much more than the figure of 16 percent for all kinds of renewables, but still less than the fossil-based power generation, which contributes almost 40 percent of the global net increase in the power demand based on coal, oil and gas. Not surprisingly, China's contribution to the future energy growth is much higher than the global share of today, especially for nuclear power.

Thus, no evidence of a shift in China's fossil energy demand is at hand, neither for the total energy sector nor the power sector alone. The share of fossil energy will decline, but the energy demand, the commissioned capacity of coal-fired power plants and increased demand of oil in the transportation sector may still continue to grow, even beyond the sustainable carrying capacity. The hard fact is that the Chinese govern- 
FIGURE 3. China's Share of Global Net-Growth in Electricity Generation: 2011-2035

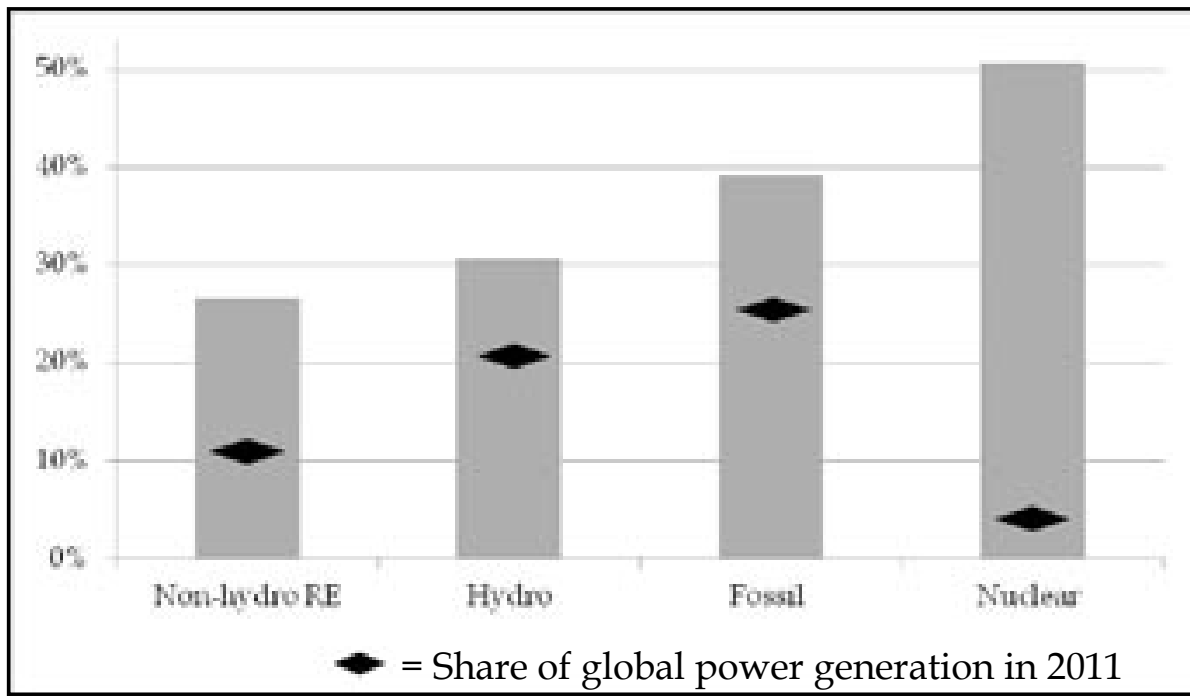

Note: The scenario is based on the assumption that all China's official goals for increased non-fossil energy are attained, i.e. IEA's New Policies Scenario.

Source: Author's calculations based on IEA's (2013B) data on electricity generation (TWh).

ment has been forced to devise new and additional green policies: a new green trend is possible. This may prove to be a serious challenge, as the government has not succeeded in meeting some important renewable energy targets in the past. In order to fully understand the present and future challenges, the specifics of local energy governance must be examined. The energy sector exhibits clear characteristics of a fragmented authoritarian mode of government, which will be decisive for China's future green development.

\section{Local Opposition to Green Energy}

China's centrally formulated green policies do not always find solid ground at the local level. Common Western assumptions about strong top-down rule by the Chinese authoritarian party-state are challenged by the fact that economic reform and administrative and economic decentralization since the 1980s have stimulated a federalist trend. This trend is rooted in the dual role of local governments in the implementation of energy policies. This is partly due to the so-called 'tiao tiao kuai kuai' administrative system, which describes the quasi-federal arrangement of administration in China. The term tiao refers to the vertical lines of authority over various sectors reaching down from the ministries of the 
central government. Kuai refers to the horizontal level of authority of the territorial government at the provincial or local level (Sinkule and Ortolano1995: 10-21). A local energy or environmental protection bureau may have reporting responsibilities to both the central government's resort ministry (Ministry of Environment) and to the local city mayor or provincial governor, but the decisive say is increasingly concentrated by the local authorities.

Thus, the unknown factor is the ability of the party-state to implement the various green policies at the local level. China's so-called de facto federalism (Andrews-Speed 2012; Montinla et al. 1996: 50-81) entails that power is increasingly decentralized and concentrated at the local level, albeit still under the direct command of the central ministry. This may well prove to be a critical barrier hindering the transition to a more green energy sector. In this context, the ability to bring down the share of coal in energy production is critical as it will conflict with interests in the coal producing areas, which produce about 50 percent of China's coal (Delman and Odgaard 2014).

More than 30 years of economic reforms have created strong local alliances between enterprise managers and government officials. Company executives have been allocated the responsibility for their company's operations and can retain a large share of profits. The economic management is often executed through a web of administrative permissions and connections, and enterprise managers and party-state officials can forge strong alliances; their mutual interests often set the local agenda. Experience shows that, apart from the leaders of some wealthy cities and provinces, they are not easily persuaded to enact costly policies and to pay more for cleaner energy, despite pressure from central government or possible protests from NGOs and local people.

Local governments are more concerned with providing jobs for the many unemployed in order to avoid social unrest. About 128 million people still live below one of the national poverty lines of RMB 2,300 per year (about US\$1.8 per day) (World Bank 2013B). If the international poverty line of the World Bank is applied (less than 1.25 US\$ per person in purchasing power parity), 9.2 percent of China's population - or 123 million people-were poor in 2010 (World Bank 2013C). With the second largest number of poor in the world after India, poverty reduction remains a fundamental challenge, and long-term investments in clean energy and a better environment may receive less priority.

The de facto authority of the local governments is evident in many ways and is relevant to the green energy sector. For example, local tinkering with 
reporting on official targets is well known, and explains why the central government is sometimes compelled to make its own investigations. After a national investigation on the local construction of energy plants in 2004, the National Development and Reform Commission revealed that construction of a large number of power plants with a combined generating capacity of $120 \mathrm{GW}$ had begun without receiving the necessary approval. This huge capacity equalled an astonishing 30 percent of China's total power generating capacity..$^{10}$ A relatively large share of these hidden, local power plants was coal-based and did not comply with national policies for high power efficiency. The local need for cheap power without lengthy approvals overruled the central policy demands for higher investments costs for green energy. To put things into perspective: this unreported construction of local power plants represented an increase in the total global energy-related $\mathrm{CO}_{2}$ emission of about 2 percent. ${ }^{11}$

A similar statistical lacuna mirroring central-local policy discrepancies is found in the reported coal consumption. A team of researchers has found significant differences between the reported energy consumption figures cited by the central government and those cited by the provinces (Guan et al.: 2012). In 2010, China's aggregated data on energy consumption from the provinces was 20 percent higher than that reported by the National Statistical Bureau. This discrepancy is mainly due to inconsistencies of coal consumption. A possible explanation is local over-reporting of GDP, which has caused a corresponding overreporting of energy consumption to match the reported GDP. Another possible explanation is that the increased focus on sustainable development and the delegated targets for achievement of 20 percent improved energy intensity during the 11th Five-Year Plan have put pressure on local governments to under-report energy consumption (Ibid.). ${ }^{12}$ The research team's analysis specifically mentioned that many small coal mines, like power plants and other polluting industries, have been shut down by order of the central government in order to improve energy efficiency; however many of them have since re-opened or moved their operation to another location. This explanation fits well with the investigation results that cited 30 percent more power capacity than officially registered. The discrepancy between central and local statistics on actual energy consumption in 2010 represents as much as 1.4 Giga Ton $\mathrm{CO}_{2}$, i.e. 5 percent of the global total, or the equivalent of the world's fourth largest emitter, Japan (Guan et al, 2012).

These findings are substantiated by another analysis of the coal statistics. After Beijing ordered a nationwide closure of many small coal- 
mines in the late 1990s, local governments' unwillingness to cooperate resulted in widespread statistical tampering, which had a serious impact on reported coal production and consumption. After two revisions in 2006 and 2010, China's national coal production for 2000 was updated with a new figure that was 39 percent higher. The quality of China's coal statistics is deteriorating over time. In 1990, China's national coal consumption equalled the summation of the provinces' coal demand. In 2000, the national figure became 4 percent lower, and this statistical discrepancy kept widening, reaching 18 percent in 2010. ${ }^{13}$

The seemingly uncontrollable local power sector expansion is also evident when examining the targets in the Five-Year Plan of 2010-2015. As mentioned above, almost 75 percent more coal-fired power plants are under construction in the present Five-Year Plan, despite an official target of only 45 percent increase. Similarly, while the Five-Year Plan put coal production capacity at 4.1 billion tons by 2015, the UOB Kay Hian bank and commodity trading group expects a consumption of at least 4.7 billion tons (Reuters Point Carbon 2014). The same development is seen in the 2012 implementation scheme of the 12th Five-Year Plan for coal, where specific regional caps were set for China's leading coal producing provinces. However, preliminary statistics suggested that the 2012 coal output in the major provinces was 12-18 percent higher than their respective caps, according to China Coal Transport and Distribution Association. ${ }^{14}$

The local preference for cheap and abundant energy for local industries appears to be a major trend, although some city governments and provinces adopt very ambitious green policies. Thus, Shanghai, Beijing, Dalian and other local governments are seriously attempting to implement more sustainable policies (Economy 2010). If the major trend is to be changed, another administrative system and incentive scheme must be adopted. Until this happens, the recent green policies may be a temporary phenomenon or a phenomenon caused by relatively low economic growth.

\section{Conclusions and Policy Perspectives}

The above quantitative analyses present a picture of a country with almost unlimited thirst for energy. All energy sectors are expanding rapidly. The government lists ambitious targets for renewable energy and nuclear power, but the demand for coal, oil and gas is still enormous.

The global impact can be summed up as follows:

- China has become a net importer of coal, gas and oil. China's de- 
pendence on imported fossil fuels will increase further, and the security of supply of oil, in particular, is alarming.

- China's energy consumption is still dominated by coal. The share of coal has declined marginally over the past 30 years, but recent data show an important growth in the share of non-fossil energy. Whether this is a temporary phenomenon or a possible new trend depends on the future development of coal-to-gas and coal-to-liquids.

- China's incremental share of renewable power has been lower than that of the US and especially Europe, which will also be the case in the five year period of 2011-2015. However, recent statistics may suggest a significant higher share of renewable power in the coming years.

- China's global share of fossil fuel-based power will increase more than its incremental share of renewable electricity towards 2035.

- China will contribute to about half of the global net growth in nuclear power, oil and coal demand towards 2035, while the shares for gas and renewables range at much lower levels.

- China's share of global $\mathrm{CO}_{2}$-emissions increases at a faster speed than its global share of energy consumption.

One may rightly argue that China has the same right to industrialize and urbanize its population as other countries, and if coal is at hand that is an obvious energy source to use. But China's dilemmas are that this path may not lead to the desired development, due to the obstacles of lack of security of supply, pollution, water scarcity in coal-endowed areas, etc.

Therefore important and ambitious green targets have been adopted by the Chinese government, but several official targets for a more sustainable energy sector have not been attained. These include:

- The Five-Year Plan target for non-fossil energy in 2006-10 was not achieved, even when nuclear power was included in the target.

- The 2010 targets for increase of non-hydro renewables were not met by half of the grid corporations and large energy companies.

- The coal-based power plants seem to be commissioned more extensively than prescribed in the present Five-Year Plan.

- The target of a maximum of 65 percent coal in primary energy demand has been postponed from 2015 to 2017, but may nevertheless be attained in 2015, if the most recent statistics signal a new trend.

Some important targets in the Five-Year Plan of 2010-2015 can be expected to be achieved. This does not signal a breakthrough for the 
government's quest for more green policies; it may also be the result of modest economic growth. Arguably, a relatively modest growth of 7 percent until 2020 and 5-6 percent in the next decade is a realistic economic growth, which will strongly support a more green energy sector in the future. This may prove to be the case.

If China's economy grows more than expected due to an end to the low international conjunctures and subsequent economic recovery, or because local governments continue to release misleading reports and tampered statistics on the actual development, then the realization of the endorsed green energy policies seems to hinge on the implementation of new and additional policies. The most important question at this stage is whether or not the central government will be able to replace bureaucratic decrees, ineffective sanctions and planning targets with more effective tools of implementation.

An important precondition is a reform of the so-called 'tiao tiao kuai kuai' administrative system, where the de facto federal governance hinders the implementation of new green energy policies. This accentuates a move away from mandatory targets for each administrative level to a more incentive-based management system. The market incentives must be based on better designed and enforced regulations. ${ }^{15}$ It is important that not only the local authorities but also non-state actors perceive their own interest as one of saving on their use of energy resources, which will be achieved when energy is properly priced. The 12th Five-Year Plan offers a number of new policies in this regard.

For instance, several carbon credit trading schemes are being implemented on a pilot basis (EIU 2013), which may be the first steps towards a unified national scheme. The specific design of such a national scheme, it's monitoring and penalties, and so on, will matter greatly and can be an effective means.

A carbon tax on the use of fossil energy by large enterprises ${ }^{16}$ is expected on a limited scale, maybe as a pilot scheme. The Ministry of Finance introduced the initiative in 2007, but a carbon tax has not yet materialized. The ministry proposed in 2010 a tax of 10 yuan/ton $\mathrm{CO}_{2}$, increasing to 50 yuan/ton in 2020. If implemented in an optimal way, the carbon tax could prove to be an important means to reduce the growth in consumption of fossil fuels. The suggested starting level of 10 yuan/ton is expected to lower GDP only modestly by 0.1 percent (Hill 2013) to 0.14 percent in 2020. ${ }^{17}$ Thus, the economic impact appears to be relatively small, but another analysis finds that a carbon tax of 100 yuan/ton would necessitate compensatory measures to certain highly 
affected industries (Wang et al. 2011: 4144-52). The lengthy process of implementation surely exposes the Chinese leadership's concerns regarding the relatively low growth rates during and after the international economic crisis. The overall economic development appears to receive higher priority than the green transformation.

Another challenge for the carbon tax merits attention. Local governments are likely to find ways to undermine the carbon tax, for example by compensating local enterprises for large carbon tax payments (Andrews-Speed 2013). It is not uncommon that the local tax bureau offers a reduction in local fees in return, often the exact same amount as the fine or charge meted out by the environmental bureaus. There are numerous examples showing that local governments help local enterprises in this way, to safeguard local employment and their own tax revenues. ${ }^{18}$ Thus, the actual design of the forthcoming carbon tax system will be of great importance if it is to raise incentives for using more green fuels and to improve energy efficiency.

Resource taxes have been imposed on fossil fuels in recent years. ${ }^{19} \mathrm{~A}$ fixed percentage is now imposed on the sales revenue from oil and gas, and a similar levy on volume of coal has been introduced, though the latter may be changed to a tax on sales revenue as currently applies to oil and gas. Clearly, the levels of these resource taxes have a crucial impact on increases in green energy. It has not yet paved the way for attainment of official targets for non-fossil fuels, but this may change in the future.

A gradual phase-out of the energy subsidies may gradually bring about true cost prices. ${ }^{20}$ In December 2011, China began testing natural gas prices linked with international prices, while the price setting of oil was gradually linked to the world market prices during the 11th Five-Year Plan. The result is higher prices for end-users. This can be combined with earmarked subsidies to vulnerable groups in order to facilitate a social consensus. The first steps in a price reform for gas is likely to bring about more market conducive prices, as has been the case with oil and coal (Andrews-Speed 2013A). While the price reforms for gas aims at improving the competitiveness of gas versus coal and to provide incentives to explore new reserves of both conventional and unconventional gas, the more advanced price reforms for oil and coal aim to alleviate the strain on state finances and to improve energy efficiency.

Electricity is subsidized, especially for residential users. In 2012, a reform introduced three-tier inclining tariffs for residential users based on consumption, i.e. the larger consumers pay a higher tariff (Lin and Jiang 2012: 164-73). As this group is typically more affluent, social ten- 
sions are avoided by protecting the low income groups that generally consume less electricity. This is likely to develop further, i.e. subsidies for greener electricity are increasingly financed by the end-users rather than the state. A similar three-tier tariff system for households will be introduced for natural gas by the end of $2015 .^{21}$

In short: important political capital has been invested in devising solutions for a more green and sustainable energy sector. Action is now taken by more effective regulation by carrot instead of stick, which may bring about new means of energy governance, if monitored and followed up by new central government initiatives. Increased social pressure from NGOs and local interest groups on the powerful local elites may also be influential, if more profound changes are to evolve.

It is still too early to pass any judgement on the possible outcomes of these new reforms and mounting political pressure. Lengthy and very locally based power struggles can be expected with a variety of different means and outcomes.

Ole Odgaard is a senior policy advisor with a PhD in economic and institutional reform in rural China. Previously employed by the Danish Ministry of Foreign Affairs and posted at the Royal Danish Embassy in Beijing 1992-1995, he is now professionally engaged with energy planning, renewable energy and combined heat and power in Denmark. He is affiliated to the think-tank ThinkChina.dk, working on issues related to China's green growth. Email: oleodg@mail.dk

\section{NOTES}

1 Even if coals share of the total energy consumption fell by 1.8 pct. points in just two years, the absolute consumption of coal increased by 4 per cent in the same period.

2 Well over 90 per cent of China's thermal power plants use water-cooling. About 12 per cent of the recycled cooling water evaporates, implying that the system needs be completely replenished every eight years. By the end of 2010, only 5 per cent of the power generation involved dry cooling. New thermal plants may be equipped with such air-cooling technology, which withdraw less water, but these technologies are more expensive to build and incur a higher coal consumption loss due to their lower energy efficiency. Thus, dry cooling causes a higher consumption coal and a higher emission of CO2 (Chan 2013).

3 Schneider, K. 2013. 'Coal is China's Largest Industrial Water Consumer'. Available at http://grist.org/article/2011-02-23-coal-is-chinas-largest-industrial-water-consumer/.

4 See Bullard, N. 2013. 'China's power utilities in hot water: Executive summary'. 
Bloomberg - New Energy Finance, 25 March 2013. Available at http://about.bnef. com/files/2013/03/BNEF_ExecSum_2013-03-25_China-power-utilities-in-hotwater.pdf.

5 BP 2011. Statistical Review of World Energy-June 2011, available at www.bp.com/statisticalreview.

6 Coal-fired power plants stand for more than half of China's total coal consumption, and emit over 40 per cent of China's SO2 and NOx pollutants. Primo 2012, China's new pollutant emissions standard for coal power plants went into effect. These standards shall bring Chinese power plants in line with developed world standards in important respects (WRI 2012A).

7 Yale University 2014. Environmental Performance Index 2014. Available at http:/ / epi. yale.edu/epi/country-profile/china.

8 Sources: The National Development and Reform Commission (NDRC), Medium and long-term Development Plan for Renewable Energy in China, September 2007; The State Council, China's Twelfth Five Year Plan (2011-2015); Hu Jintao, Speech to UN General Assembly September 2009, New York Times, 22 September 2009; Bloomberg, 'Will China's New Renewable Portfolio Standard Boost Project Development?', Renewable energy - Research Note, 11 May 2012; International Energy Agency, Understanding China's 12th Five-Year Plan, February 2013, IEA/SGD(2013)9. Guo Fa [2013], No.37 State Council, Beijing, 2013; Simon Quemin \& Wen Wang, Overview of Climate Change Policies and Development of Emissions Trading in China, Information and Debate Series, No. 30, March 2014, Paris-Dauphine University; IEA, China's Climate Policy, 5 January 2015, IEA/SGD(2015)2.

9 China's share of the global net-growth in nuclear energy does not correspond to the seemingly same share shown in Figure 3. This figure shows the net-growth in total energy demand, which includes transmission loss of energy etc., while Figure 3 shows the electricity generation without loss of process energy, etc.

10 China Daily, 29 November 2004.

11 Own calculation based on data from IEA 2012C: 5; and IEA 2012B.

12 The 20 per cent low figure for energy consumption is the official data. This figure of 3,249 million ton coal equivalents is also listed in Table 1.

13 Jianjun Tu, K. 2012. 'China's Problematic Coal Plan'. The Diplomat, 18 April 2012. Available at http:/ / thediplomat.com/2012/04/chinas-problematic-coal-plan/.

14 China Oil Trader 2013. 'China's Plan to Cap Coal Consumption and Production Needs Political Accountability and Accurate Statistical Reporting to Succeed', 28 January 2013, at http:/ / www.chinaoiltrader.com/?p=364.

15 In China, the maximum statutory fine for refusing to report emissions data is only 50,000 yuan and penalties for exceeding emission standards can only reach twice that at 100,000 yuan. See Andrews, S. 2013. 'How Beijing Hid the Smog'. Wall Street Journal, 5 February 2013. Available at http://online.wsj.com/news/articles/SB1 0001424127887324445904578285560136861562 . Andrews 2013). The penalties are expected to be raised in the near future.

16 The Draft Law on Addressing Climate Change, published in May 2012, includes mention of both cap-and-trade schemes and a carbon tax. Already in 2010, the Ministry of Finance suggested levying a carbon tax in 2012 at 10 yuan per ton CO2, which should increase to 50 Yuan per ton by 2020. People's Daily, 20 February 2013. The stated time for the commence of carbon tax was later excluded due to a lower than expected economic growth. See Lin, L. 2013. 'No timetable for carbon tax say Chinese official'. China Dialogue. Available at https://www.chinadialogue.net/article/show/single/en/6242-No-timetable-for-carbon-tax-say-Chinese-officials.

17 WRI 2013A. Based on the Harvard China Project, Clearer Skies Over China: Reconciling 
Air Quality, Climate, and Economic Goals, (2013, MIT Press). Another thorough study finds that a carbon tax of 50 Yuan/ton will reduce GDP by 0.19 per cent. This tax rate would reduce $\mathrm{CO} 2$ emission by 3.1 per cent compared to a business-as-usual scenario, which is much lower than the 19 per cent found in the above WRI study (Lu et al. 2010).

18 Economist, 19 August 2004. 'China's environment: A great wall of waste'. A broad study of environmental legal proceedings in China has shown that half of the charges brought against enterprises were turned down by local authorities, including the local party organization, based on the argument that the outcome of such cases could threaten local social stability, something which is a prime concern for the party-state (Wang 2010).

19 The National Bureau of Taxation reports that resource tax revenue rose from 6,286 billion Yuan in 1999 to 30,164 billion yuan in 2008, but declined slightly as a proportion of total tax revenues from 0.61 per cent to 0.52 per cent over the same period (IISD and CNREC 2013: 4).

20 Based on an input-output model analysis of China's energy prices, the magnitude of China's subsidies amounted to 4.04 per cent in 2008 (Jiang and Tan 2013). According to IEA, China has the sixth largest energy subsidies in the world (IEA 2013B: 95).

21 See Thomson Reuter. 'China to introduce tiered gas prices for household users.' 21 March 2014. http://uk.reuters.com/article/2014/03/21/china-gas-pricingidUKL3N0MI2H220140321. Accessed 29 April 2015.

\section{REFERENCES}

ADB (Asian Development Bank) 2012. Toward an Environmentally Sustainable Future - Country Environmental Analysis of the People's Republic of China. Mandaluyong City.

Andrews-Speed, P. 2012. 'China's long road to a long-carbon economy'. Transatlantic Academy Paper Series. May 2012. Washington DC.

Andrews-Speed, P. 2013. China's proposed carbon tax. 17 March 2013. http://www. andrewsspeed.com/chinas-proposed-carbon-tax. Accessed 29 April 2015.

Andrews-Speed, P. 2013A. China's new gas pricing system. Towards the market? 17 August 2013. http://www.andrewsspeed.com/chinas-new-gas-pricing-system-towardsthe-market/. Accessed 29 April 2015.

Birol, F. 2013. Chief Economist of International Energy Agency Faith Birol at presentation of World Energy Outlook 2013. Copenhagen, 26 November 2013.

Bloomberg 2012. 'Will China's new Renewable Portfolio Standard boost project development?' Renewable Energy - Research Note, 11 May 2012.

Chan, Wai-Shih 2013. 'The water challenge facing China's coal and power sector is 'inescapable", China Dialogue, 8 July 2013. https:/ / www.chinadialogue.net/article/ show/single/en/6187-The-water-challenge-facing-China-s-coal-and-power-sectoris-inescapable-. Accessed 29 April 2015.

Chen, Yuyu; A. Ebenstein; M. Greenstone; and Hongbin Li 2013. 'Evidence on the impact of sustained exposure to air pollution on the life expectancy from China's Huai River policy.' Proceedings of the National Academy of Sciences, PNAES 111: 5. http://www.pnas.org/content/early/2013/07/03/1300018110.full.pdf+html. Accessed 29 April 2015.

CNREC 2013. 2012 - China Renewable Energy Outline. China National Renewable Energy Centre, Beijing.

Delman, J. and O. Odgaard 2014. 'From 'Worn' to 'Green' China-model? Energy in 
the 12th five-year plan in an environmental and climate change perspective.' In E. Moe and P. Midford (eds), Common Challenges, National Responses. Basingstoke: Palgrave Macmillan.

Economy, E. 2010. The River Runs Black. Ithaca: Cornell University Press.

EIU 2013. The Economist Intelligence Unit, Trials and Tribunals - China experiments with carbon trading.

FAO 2011. Irrigation in Southern and Eastern Asia - Aquastat Survey 2011. Rome.

Guan, Dabao; Zhu Liu; Yong Geng; Sören Lindner and Klaus Hubacek 2012. 'The gigatonne gap in China's carbon dioxide inventories'. Nature Climate Change.http:/ / www.nature.com/nclimate/journal/v2/n9/full/nclimate1560.html. Accessed 29 April 2015.

Health Effect Institute 2013. 'WHO, Global Burden of Disease Study.' http://www. healtheffects.org/international.htm. Accessed 29 April 2015.

Hill, S. 2013. Reforms for a Cleaner, Healthier Environment in China. OECD Economics Department Working Papers, No. 1045. Paris: OECD Publishing.

Holdaway, J. 2013. 'Environment and Health Research in China: The State of the Field'. China Quarterly 214 (June): 255-282.

$\mathrm{Hu}$, Jintao 2009. Speech to UN General Assembly. Reported in New York Times. 22 September 2009. http://www.nytimes.com/2009/09/23/world/asia/23hu.text. html?_r=0. Accessed 29 April 2015.

IEA 2011. World Energy Outlook 2011. Paris: OECD Publishing.

IEA 2012. Coal Information 2012. Paris: OECD Publishing.

IEA 2012A. World Energy Outlook 2012. Paris: OECD Publishing.

IEA 2012B. CO2 Emissions from Fuel Combustion. Paris: OECD Publishing.

IEA 2012C. 'Policy Options for Low-Carbon Power Generation in China.' Insights Series 2012. Paris: OECD Publishing.

IEA 2013. Redrawing the Energy-Climate Map. World Energy Outlook Special Report. Paris: OECD Publishing.

IEA 2013A. 'China And Other Partner Countries In The Medium-Term Outlook For Coal, Standing Group for Global Energy Dialogue.' Presentation on 12 February 2013, IEA/SGD(2013)10.

IEA 2013B. World Energy Outlook 2013. Paris: OECD Publishing.

IEA 2013C. 'Understanding China's 12th five-year plan.' Presentation on February 2013, IEA/SGD(2013)9.

IEA 2013D.Gas Information 2013. Paris: OECD Publishing.IEA 2013E. Coal Information 2013. Paris: OECD Publishing.

IEA 2013F. Coal - Medium-Term Market Report 2013. Paris: OECD Publishing.

IEA 2014. Gas, Coal and Power Market Update. 19 November 2014, IEA/GB(2014)58.

IEA 2014A. China's Climate Policy. Presentation on 5 January 2015, IEA/SGD(2015)2.

IISD \& CNREC (International Institute for Sustainable Development \& Chin National Renewable Energy Centre) 2013. Green Revenues for Green Energy: Environmental fiscal reform for renewable energy technology deployment in China. Summary for Policy-Makers. Manitoba, Canada.

IRENA 2014. Renewable Energy Prospects; China. Abu Dhabi.

Jiang, Zhujun and Jijun Tan 2013. 'How the removal of energy subsidy affects general price in China: A study based on input-output model.' Energy Policy 63 (C): 599-606.

Jianjun Tu, K. and S. Johnson-Resier 2012. Understanding China's Rising Coal Imports. Washington DC: Carnegie Endowment for International Peace.

Lieberthal, K. and M. Oksenberg 1988. Policy Making in China. Leaders, Structures and Processes. New Jersey: Princeton University Press.

Lin, B. and Z. Jiang 2012. 'Designation and influence of household increasing block 
electricity tariffs in China.' Energy Policy 42: 164-173.

Lu, Cuanyi; Qing Tong and Xuemei Liu 2010. 'The impacts of carbon tax and the complementary policies on Chinese economy.' Energy Policy 28(11): 7278-7285.

Ministry of Environmental Protection 2012. Report on the State of the Environment in China 2011. Beijing.

Montilna, G.; Yingyi Qin and B. Weingast 1996. 'Federalism, Chinese Style: The Political Basis for Economic Success.' World Politics 48(1): 50-81.

National Statistical Bureau 2014. Statistical Yearbook of China 2014. Beijing. Available at http://www.stats.gov.cn/tjsj/ndsj/2013/indexeh.htm; and http://www.stats. gov.cn/tjsj/ndsj/2014/indexeh.htm. Accessed 29 April 2015.

NDRC 2007. Medium and long-term Development Plan for Renewable Energy in China, Beijing.

Odgaard, O. and J. Delman 2014. 'China's Energy Security and its Challenges Towards 2035.' Energy Policy 71: 107-117.

Quemin, S. and W. Wang 2014. 'Overview of Climate Change Policies and Development of Emissions Trading in China.' Information and Debate Series 30. Paris: ParisDauphine University.

REN 21 2012. Renewables 2012 - Global Status Report. Paris.

REN 21 2013. Renewables 2013 - Global Status Report. Paris.

REN 21 2014. Renewables 2014 - Global Status Report. Paris.

Reuters Point Carbon 2014. 'China approves massive new coal capacity despite pollution fears.' 8 January 2014. http:/ / www.reuters.com/article/2014/01/07/chinacoal-idUSL3N0K90H720140107. Accessed 29 April 2015.

Run, Wang; Wenjuan Liu; Lishan Xiao; Jian Liu and W. Kao 2011. 'Path towards achieving of China's 2020 carbon emission reduction target - A discussion of low-carbon energy policies at province level.' Energy Policy 39(5): 2740-2747.

Sinkule, B.J. and L Ortolano 1995. Implementing Environmental Policy in China. Westport: Praeger Publishers: 10-21.

Solidiance 2013. China's Renewable Energy Sector - An overview of the key sectors. Singapore.

State Council 2012. China's Twelfth Five Year Plan (2011-2015), Beijing.

State Council 2013. State Council on the issuance of air pollution prevention and control action plan. No. 37. Beijing.

Wang 2010. 'China's green laws are useless'. China Dialogue. 23 September 2010. Available at http://www.chinadialogue.net/article/show/single/en/3831--China-sgreen-laws-are-useless-. Accessed 29 April 2015.

Wang, Xin; Ji Feng and Ya Xiong Zhang 2011. 'An analysis on the short-term sectoral competitiveness impact of carbon tax in China'. Energy Policy 39(7): 4144-4152.

World Bank 2013. China Data. Available at http://data.worldbank.org/country/ china.

World Bank 2013A. World Development Indicators 2013. Available at http:/ / wdi.worldbank.org/table/3.5. Accessed 29 April 2015.

World Bank 2013B. China Overview. Available at http://www.worldbank.org/en/ country/china/overview. Accessed 29 April 2015.

World Bank 2013C. World Bank Poverty Indicators. Available at http:/ / data.worldbank. org/indicator/SI.POV.DDAY/countries?display=default. Accessed 29 April 2015

World Bank \& Development Research Center of the State Council 2012. China 2030 - Building a Modern, Harmonious, and Creative High-Income Society. Washington DC: World Bank.

WRI 2012. WRI Insights. 'New Global Assessment Reveals Nearly 1,200 Proposed Coal-Fired Power Plants'. 20 November 2012. Available at http://insights.wri. 
org/news/2012/11/new-global-assessment-reveals-nearly-1200-proposed-coalfired-power-plants\#sthash.nK4l2JG5.dpuf.

WRI 2012A. 'China Adopts World-Class Pollutant Emissions Standards for Coal Power Plants.' China FAQ. 15 June 2012. Available at http:/ / www.chinafaqs.org/files/chinainfo/China\%20FAQs\%20Emission\%20Standards\%20v1.4_0.pdf.

WRI 2013. 'Majority of China's Coal-Fired Power Plants located in Water-Stressed Regions.' 5 September 2013. Available at http://www.chinafaqs.org/blog-posts/ majority-china $\%$ E2\% $80 \% 99$ s-proposed-coal-fired-power-plants-located-waterstressed-regions.

WRI 2013A. 'Clearer Skies over China - Coping with Dirty Air and Climate Change.' China FAQ. December 2013. Available at http://www.chinafaqs.org/files/chinainfo/ChinaFAQs_Clearer_Skies_Over_China_0.pdf.

Yang, Ailun 2012. 'What is the future of King Coal in China? World Resource Institute.' 12 October 2012. Available at http://www.wri.org/blog/what-future-king-coalchina. Accessed 29 April 2015. 